\title{
Perception and Efficiency Analysis of Agricultural Cooperatives: A Case Study in Hau Giang Province, Vietnam
}

\author{
Tien Dung Khong
}

School of Economics, Can Tho University, Vietnam

\begin{abstract}
This research aims to evaluate the perception and productive efficiency of agricultural cooperatives in Hau Giang province Vietnam. The main contribution of this paper is the comparison between two types of cooperatives including fruit cooperatives (jackfruit, lemon) and rice cooperatives representing new and conventional forms, respectively. The primary data in this research was obtained by directly interviewed 50 cooperatives. Descriptive statistics, t-test, financial indicators, Likert scale, and SWOT matrix were employed to analyze the data. Descriptive statistics and comparative methods were first employed to assess the current state of cooperatives through criteria such as capital resources, age of cooperatives, number of members, age, education level of the cooperative head. Likert scale was then employed to identify perceptions and desires in order to enhance cooperative activities through several suggestions combine with SWOT matrix analysis. The analysis of the current situation identifies that the cooperative is increasing in quantity and quality, creating more job opportunities for its members and diversifying services. However, the weaknesses of cooperatives include organizational capacity, infrastructure conditions, unstable output prices and export markets, and poor competitiveness. The comparison results reveal that fruit cooperatives are more effective than rice cooperatives, but the differences are not statistically significant. The SWOT matrix analysis proposes some innovation strategies for agricultural cooperatives, including focusing on diversifying forms of activities and organizing market linkages with businesses, supporting product output; increase operational capital
\end{abstract}

through capital mobilization, infrastructure investment, market consolidation, and technical development, as well as capacity building of cooperatives through training.

Keywords: cooperatives, financial efficiency, linkages, Mekong River Delta

\section{INTRODUCTION}

The Mekong River Delta (MRD) is the main agricultural production area of Vietnam, contributing more than $50 \%$ of rice and fruit production and about $90 \%$ to the country's agricultural exports (GSO, 2020). The MRD currently has nearly 2,400 official and non-officials cooperatives, 11 unions of cooperatives, and more than 17,000 forms of organizations. In particular, the cooperative form is popular and quite effective when many cooperatives are doing well the role of linking production and consumption of products with enterprises, in which enterprises provide inputs, techniques while cooperatives represent farmers in making the contract (Vietnam Cooperative Alliance, 2019). Cooperatives have performed the function of orienting, organizing, and guiding farmers to apply modern techniques into production, transforming the structure of crops when necessary, and contributing to the construction of modern rural areas with the province (Vietnam Cooperative Alliance, 2019). However, there are also many difficulties such as small production scale, limited human resources, especially lacking qualified staff to manage and operate service activities, and mainly domestic 
market consumption only (Chu Hoang Hiep, 2015). Besides, most of the cooperatives are still confused in the direction of operation, investment, and development of production and business; there are no good products and services to meet current consumer demand; lack of close linkage between cooperatives and farmers result in a weak performance of cooperatives. The formation of production and consumption chains between farmers, enterprises, and farmer organizations is still limited and inadequate (GSO, 2020). In order to orient the development of collective economy and cooperatives in the next 10 years, on March 12, 2021, the Vietnam Prime Minister signed and promulgated Decision No. 340/QD-TTg approving the Strategy for collective economic development and the cooperative period 2021-2030, with the well-defined goal of promoting this type of economy following objective laws, based mainly on science and technology, innovation and digital transformation. Therefore, it is necessary to investigate the current status and effectiveness of cooperatives in the current period to propose a suitable development plan.

\section{LITERATURE REVIEW}

In developing countries, the roles of cooperatives are important to the economy and are a dominant form in the agricultural sector. Productive efficiency between cooperatives and investor-owned is still unclear (Monteiro \& Straume, 2018; Soboh et al., 2012). Although previous research focuses o investigating differences between cooperatives and other forms of organizations (Sexton \& Iskow, 1993), the efficiency of cooperatives themselves and objective information from cooperatives are necessary. Research on cooperatives has been carried out in recent years to evaluate factors affecting the results of agricultural cooperatives (Duong Ngoc Thanh et al., 2018; Bui Thong Nhat, 2010) or research about solutions to improve the operational efficiency of agricultural cooperatives (Nguyen Van Tuan, 2013; Nguyen Cong
Binh, 2007; Nguyen Thien Phuc, 2011) or determine the current status of production and business activities of cooperatives in the agricultural sector (Do Thi Hong Hanh, 2018). In addition, there are also studies specifically analyzing the role of agricultural cooperatives in linking consumption for rice products (Nguyen Tien Dinh and Hoang $\mathrm{Vu}$ Giang, 2016). In general, in these studies, the main approach is descriptive statistics (Nguyen Van Tuan, 2013; Duong Ngoc Thanh et al., 2018; Nguyen Cong Binh, 2007; Do Thi Hong Hanh, 2018; Nguyen Thien Phuc, 2011; Nguyen Van Tuan and Nguyen Van Sanh, 2015) or cost-benefit analysis method (Nguyen Thien Phuc, 2011; Duong Ngoc Thanh et al., 2018), SWOT matrix method (Nguyen Van Tuan, 2013; Nguyen Thien Phuc, 2011; Bui Thong Nhat, 2010) or others applying regression analysis (Nguyen Thien Phuc, 2011; Duong Ngoc Thanh et al., 2018; Nguyen Tien Dinh \& Hoang Vu Giang, 2016) to describe the status of establishment and operation, compare and evaluate the change in cooperatives performance, test hypothesis about influencing factors.

Some of the outstanding results of the cooperative when participating in the linkage between farmers and businesses today are through 3 forms of acting as a bridge between businesses and member households, organizing production, and purchasing rice of the members then sell them back to partners; and represent members to sign sales contracts with enterprises (Nguyen Tien Dinh and Hoang $\mathrm{Vu}$ Giang, 2016). Among the factors affecting the performance of cooperatives, factors include management capacity, professional qualifications, awareness of cooperatives, capital, market access (Bui Thong Nhat, 2010), machine ownership (Nguyen Van Tuan, 2013) are the most influential factors. The research results show that the production and business efficiency of agricultural cooperatives is unstable and the use of capital is not efficient, and the efficiency in using 
business and services among cooperatives is not uniform (Nguyen Cong Binh, 2007). The efficiency of production and business activities of agricultural cooperatives is not high, only $55 \%$ of agricultural cooperatives are classified as strong, the rest are medium/weak (45\%) (Nguyen Van Tuan, 2013). The results also show that the difficulty of the cooperative is the lack of capital due to the low capital contribution of the cooperative members, the small scale of operation due to the low land area managed by the cooperative members (because the cooperative members participating in the cooperative have a small amount of land), small production land area with the lowest is only 0.2 ha). Besides, the regression results show that the efficiency of production and business activities of the cooperative is affected by the following factors: the year of establishment of the cooperative, the source of capital, the management level of the board of directors, and the form of operation of the cooperative (Duong Ngoc Thanh et al., 2018). The operational efficiency of agricultural cooperatives is effective, however, most cooperatives do not have offices, most of them lack equipment and machinery. In addition, the business performance of the cooperative is still quite low, the ability to access credit is only about 4\% (Do Thi Hong Hanh, 2018).

Thus, previous studies have shown many strengths, weaknesses, and limitations of cooperatives. However, comparative studies on types of activities, comparisons between new and traditional forms have not been carried out. This study is expected to provide information to provide scientific arguments and add appropriate recommendations to develop cooperation shortly.

\section{MATERIALS \& METHODS}

This study uses both primary and secondary data for analysis, secondary data was collected from reports in local departments, reports of Vietnam cooperative alliance and cooperatives, and the annual report of the Department of Agriculture in the local province.

Primary data was collected by directly interviewing the cooperative managers who are the director or deputy director. In addition, the study also conducted expert interviews with local agricultural officers who are knowledgeable about the production situation and activities of the cooperative. This study used the following methods to analyze the data:

Descriptive and comparative statistical methods: to describe and compare indicators such as the number of cooperatives members, establishment, the field of operation, personnel structure, cultural and professional qualifications, assets, equipment, and fund sources to describe the status and operation of agricultural cooperatives in the chain of agricultural product linkages.

Cost Return Analysis (CRA): was employed in analyzing the performance of a production model. In this study, CRA was used to evaluate the overall performance of agricultural cooperatives.

SWOT matrix: was used to analyze the strengths, weaknesses, opportunities, and threats of the cooperative, thereby serving as a scientific basis to propose relevant recommendations.

T-test: to test the differences between two different groups of cooperatives (rice and perennial fruit) in terms of education level, professional level, and other factors related to socio-economic characteristics and financial performance of cooperatives. From there, it is possible to provide accurate and suitable solutions for each type of model to help agricultural cooperatives operate more effectively.

The 5-points Likert scale: is employed to analyze desired and effective activities to help cooperatives operate more effectively, including activities such as diversifying products by strengthening links with processing enterprises, offering contract price, signing a contract for technical support, and disease coverage with the 
Tien Dung Khong. Perception and efficiency analysis of agricultural cooperatives: a case study in Hau Giang province, Vietnam.

enterprise, drying storage, and transportation.

\section{RESULT AND DISCUSSION}

Table 1. The increase in the number of cooperative members

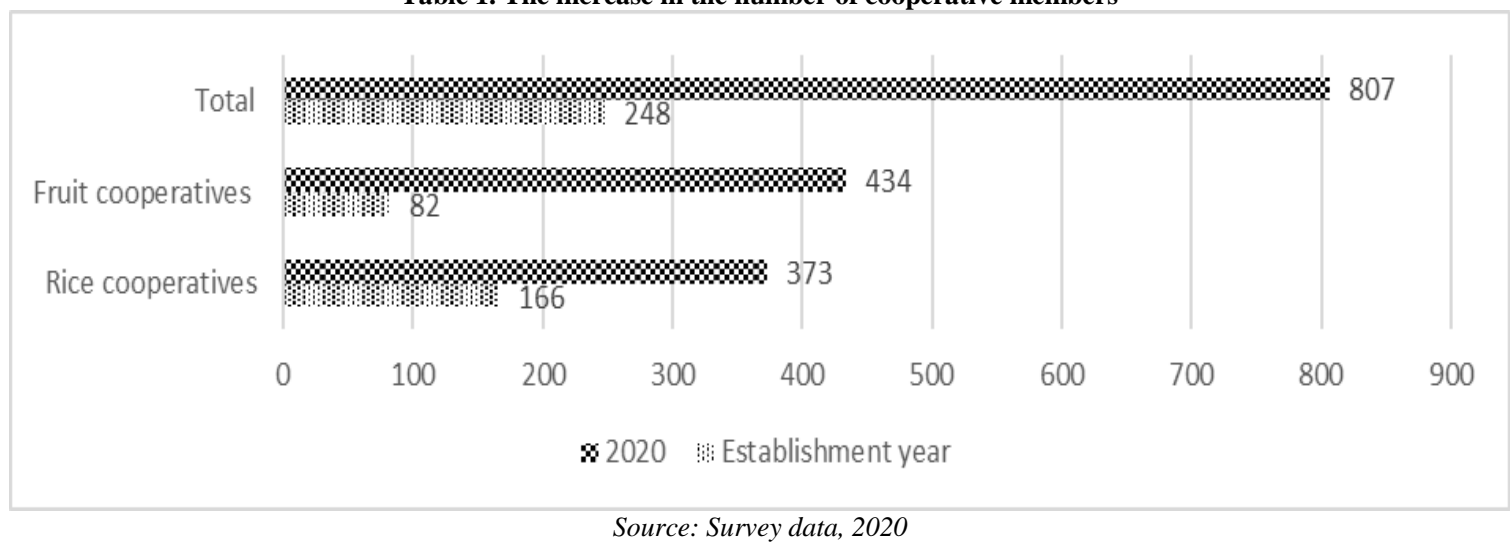

The data illustrates that the number of members of agricultural cooperatives tends to increase significantly compared to the time of establishment. In 2020, agricultural cooperatives in the field of rice have increased by 207 members (about $225 \%$ compared to the year of establishment), the fruit cooperatives increased by 352 members (about 530\% compared to the year of establishment). Majority of cooperatives holding the members under 100 (account for more than $70 \%$ ). While the agricultural cooperatives with the larger members are mainly providing diverse services (agricultural inputs, irrigation pumps, seed), agricultural cooperatives with the lowest number of members are 7 members, assist in agricultural products selling only. This indicates the fact that the operation scale of the cooperatives is still very small and has not been able to mobilize many members to join the cooperatives. At the same time, the KIP interview results also reveal the limitations that many of these cooperatives aspects, such as the efficiency of production and business activities is still low, the members do not have a clear understanding of the principles of organization and management of the cooperative, understanding the advantages of the cooperatives, the difference between the rights and obligations of members is not clear, many members are not active, make efforts to rise and are slow to adapt to the market mechanism, still relying on the support and subsidies from the local government. Therefore, the cooperatives have not been able to create tight linkages among their members and the cooperative or mobilize other members to join the cooperative.

\section{Current status of the cooperatives management board}

The management board of the cooperatives is described as follows.

\begin{tabular}{|c|c|c|c|c|c|c|c|c|}
\hline \multirow[b]{2}{*}{$\begin{array}{l}\text { Age } \\
\text { category }\end{array}$} & \multicolumn{2}{|c|}{ Chairman } & \multicolumn{2}{|l|}{ Director } & \multicolumn{2}{|c|}{ Supervisory board } & \multicolumn{2}{|c|}{ Accountant } \\
\hline & Number & $\begin{array}{l}\text { Proportion } \\
(\%)\end{array}$ & Number & $\begin{array}{l}\text { Proportion } \\
\text { (\%) }\end{array}$ & Number & $\begin{array}{l}\text { Proportion } \\
(\%)\end{array}$ & Number & $\begin{array}{l}\text { Proportion } \\
(\%)\end{array}$ \\
\hline$<40$ year & 0 & 0 & 5 & 10 & 10 & 20 & 40 & 80 \\
\hline $40-50$ year & 30 & 60 & 20 & 40 & 10 & 20 & 5 & 10 \\
\hline $50-60$ year & 5 & 10 & 10 & 20 & 20 & 40 & 0 & 0 \\
\hline$>60$ year & 15 & 30 & 15 & 30 & 10 & 20 & 5 & 10 \\
\hline Total & 50 & 100 & 50 & 1 & 50 & 100 & 50 & 100 \\
\hline Mean & & 52.2 & & 52.7 & & 52.3 & & 37.8 \\
\hline Max. & & 69 & & 69 & & 70 & & 68 \\
\hline Min. & & 42 & & 38 & & 35 & & 25 \\
\hline Std. Dev. & & 10.35 & & 10.57 & & 12.16 & & 12.85 \\
\hline
\end{tabular}


In general, the age of the management board of the cooperative is relatively high, there is no similarity in age among the members of the management board of the cooperative, so this is a difficult problem in fostering and training in order to strengthen cohesion among members through coordination in the management and operation of cooperatives. This is also the inherent characteristic of the cooperatives in the region, the ability to organize and lead is still in a conventional way, but the way of operation is only suitable for the limited organizational size, therefore, difficult to adapt to the market modernization.

Table 3. Education level of the management board of the cooperatives

\begin{tabular}{|c|c|c|c|c|c|c|c|c|}
\hline \multirow[b]{2}{*}{ Level } & \multicolumn{2}{|c|}{ Chairman } & \multicolumn{2}{|l|}{ Director } & \multicolumn{2}{|c|}{ Supervisory board } & \multicolumn{2}{|c|}{ Accountant } \\
\hline & Number & $\begin{array}{l}\text { Proportion } \\
(\%)\end{array}$ & Number & $\begin{array}{l}\text { Proportion } \\
(\%)\end{array}$ & Number & $\begin{array}{l}\text { Proportion } \\
(\%)\end{array}$ & Number & $\begin{array}{l}\text { Proportion } \\
(\%)\end{array}$ \\
\hline Primary school & 0 & 0 & 5 & 10 & 5 & 10 & 0 & 0 \\
\hline $\begin{array}{l}\text { Secondary } \\
\text { school }\end{array}$ & 20 & 40 & 30 & 60 & 35 & 70 & 15 & 30 \\
\hline High school & 30 & 60 & 15 & 30 & 10 & 20 & 35 & 70 \\
\hline Total & 50 & 100 & 100 & 100 & 50 & 100 & 50 & 100 \\
\hline Mean & & 2.6 & & 2.2 & & 2.1 & & 2.7 \\
\hline Max. & & 3 & & 3 & & 3 & & 3 \\
\hline Min. & & 2 & & 1 & & 1 & & 2 \\
\hline Std. Dev. & & 0.52 & & 0.63 & & 0.58 & & 0.48 \\
\hline
\end{tabular}

Source: Survey data, 2020

This result indicates that the educational level of the management board is relatively low. $60 \%$ of the chairman only finished high school. Regarding the directors of cooperatives, the education level is quite low, 60\% are secondary school. Similar to the supervisory board, $70 \%$ are level 2 , causing many difficulties in management, meeting the needs of market competition, and product development for the cooperative. However, they are senior farmers elected by members, experienced in production, and reputable. For accountants, the education level is quite high, $70 \%$ reaching level 3. This is a resource with an element of agility, sensitivity, and initiative in grasping the situation of cooperative development. However, in the face of new requirements and challenges in operations, operating according to the market mechanism, the improvement of knowledge through training programs has been facing great obstacles with the new role in management and control of cooperatives.

Table 4. Education level between rice cooperatives and fruit cooperatives

\begin{tabular}{|l|l|l|l|l|}
\hline & Quantity & Mean & Std. Dev. & Diff. \\
\hline Rice & 100 & 2.35 & 0.15 & $-0.95^{*}$ \\
\hline Fruit & 100 & 3.3 & 0.5 & \\
\hline \multicolumn{4}{|c|}{ Source: Survey data, 2020} \\
\end{tabular}

Note: *** and * are statistically significant at $1 \%$ and $10 \%$ level, respectively and $n s$ is not statistically significant; 0 is noneducation, 1, 2, 3 stand for primary school, secondary school, and high school, respectively
When comparing the educational level of the cooperative management team by the field of rice and fruit trees, it shows that the cooperative is in the field of fruit trees with the board of directors having a high level of education. The average qualification is level 3 while the rice cooperative is at level 2 . This reflects the fact that fruit cooperatives are newly established so the members of the management board are usually more qualified and this is the strength of these cooperatives.

The professional level of the management board is relatively low. Meanwhile, the average number of untrained agricultural cooperative managers accounts for $60 \%$. This comes from the fact that the management team of the cooperatives is often local long-time agricultural producers, appointed to the members of the Board of Directors of the cooperatives, they are often not trained in school but is have many years of experience with the locality and this sector. Over the past time, the training to improve the capacity of the management team of cooperatives has always been interested in local authorities at all levels. Many training and retraining courses have been opened to provide training on management, 
Tien Dung Khong. Perception and efficiency analysis of agricultural cooperatives: a case study in Hau Giang province, Vietnam.

administration, and professional knowledge for them. However, the number of participants in training and retraining courses is very small and the actual effectiveness is not high due to inappropriate training policies (short training time, training materials, the awareness level of the management team is still limited), not attractive, encouraging to improve qualifications.

Table 5. Professional qualifications of the management team of the cooperative

\begin{tabular}{|c|c|c|c|c|c|c|c|c|}
\hline & \multicolumn{2}{|c|}{ Chairman } & \multicolumn{2}{|l|}{ Director } & \multicolumn{2}{|c|}{ Supervisory board } & \multicolumn{2}{|c|}{ Accountant } \\
\hline Level & Number & $\begin{array}{l}\text { Proportion } \\
(\%)\end{array}$ & Number & $\begin{array}{l}\text { Proportion } \\
(\%)\end{array}$ & Number & $\begin{array}{l}\text { Proportion } \\
(\%)\end{array}$ & Number & $\begin{array}{l}\text { Proportion } \\
(\%)\end{array}$ \\
\hline Non-educated & 20 & 40 & 35 & 70 & 40 & 80 & 25 & 50 \\
\hline $\begin{array}{l}\text { Vocational } \\
\text { education }\end{array}$ & 15 & 30 & 5 & 10 & 5 & 10 & 0 & 0 \\
\hline College/ Univeristy & 10 & 20 & 10 & 20 & 5 & 10 & 25 & 50 \\
\hline Total & 50 & 100 & 50 & 100 & & 100 & & 100 \\
\hline Mean & & 4.2 & & 2.2 & & 1.4 & & 4 \\
\hline Max. & & 8 & & 8 & & 8 & & 8 \\
\hline Min. & & 0 & & 0 & & 0 & & 0 \\
\hline Std. Dev. & & 3.71 & & 3.58 & & 2.99 & & 4.22 \\
\hline
\end{tabular}

Table 6. Professional qualifications between rice cooperatives and fruit tree cooperatives

\begin{tabular}{|l|l|l|l|l|}
\hline & Quantity & Mean & Std. Dev. & Diff. \\
\hline Rice & 100 & 3.2 & 0.83 & $0.5 \mathrm{~ns}$ \\
\hline Fruit & 100 & 2.7 & 0.85 & \\
\hline \multicolumn{4}{|c|}{ Source: Survey data, 2020 } \\
\hline
\end{tabular}

Note: *** and * are statistically significant at $1 \%$ and $10 \%$ level, respectively and $n$ s is not statistically significant; $4:$ not trained, 5 , 6: vocational education, 7: college, 8: University

Although the educational level of the fruit cooperatives management board is higher than that of rice, interestingly, the difference in qualifications is not statistically significant. This also reflects the fact that rice cooperatives have received quite a lot of investment from local authorities in recent years, so their qualifications are relatively good by training regularly.

\section{Financial efficiency analysis of cooperatives}

The survey results show that, unlike the old form of cooperatives, most of the current cooperatives in the study area have official financial statements reflecting the business results. Common services that agricultural cooperatives are currently performing are agricultural supporting services, pesticide and fertilizer services, seed production and assisting consumption, and mechanization services. When comparing the two types, fruit cooperatives perform less service, which reflects the real situation when rice production is old and requires more machinery and equipment.
Table 7. Details of services provided by cooperatives

\begin{tabular}{|l|l|}
\hline Rice cooperatives & Fruit cooperatives \\
\hline $\begin{array}{l}\text { Seed supply and consumption } \\
\text { supporting }\end{array}$ & $\begin{array}{l}\text { Seed supply and consumption } \\
\text { supporting }\end{array}$ \\
\hline Agricultural service & None \\
\hline $\begin{array}{l}\text { Agricultural input supply } \\
\text { service }\end{array}$ & $\begin{array}{l}\text { Agricultural input supply } \\
\text { service }\end{array}$ \\
\hline Mechanical service & None \\
\hline \multicolumn{2}{|l|}{ Source: Survey data, 2020 }
\end{tabular}

Based on the financial reports, the financial performance of cooperatives is showed below.

In general, the financial indicators indicated the efficiency of rice is lower than that of fruit, in addition, the cost of rice cooperatives is lower than that of fruit trees. However, the difference is not statistically significant. This can be explained by the fact that the difference between the highest and lowest cooperatives in each group does not show a significant difference. Through the profit-to-cost ratio (profit/cost) (meaning how much profit will be gained for every dollar of cost), specifically, the profit/cost of rice agricultural cooperatives is as low as 0.02 . That means spending one dollar of the cost will achieve 0.02 VND of profit. These indicators are lower in rice cooperatives, reflecting the reality of this kind of product performance. The reason fruit cooperatives are effective is due to their large investment and huge production area, while the difference between the two kinds forms of current cooperatives mainly coming from the input prices, selling product price, and 
Tien Dung Khong. Perception and efficiency analysis of agricultural cooperatives: a case study in Hau Giang province, Vietnam.

the linkages among enterprises and cooperatives.

Table 8. The financial efficiency of rice and fruit cooperatives

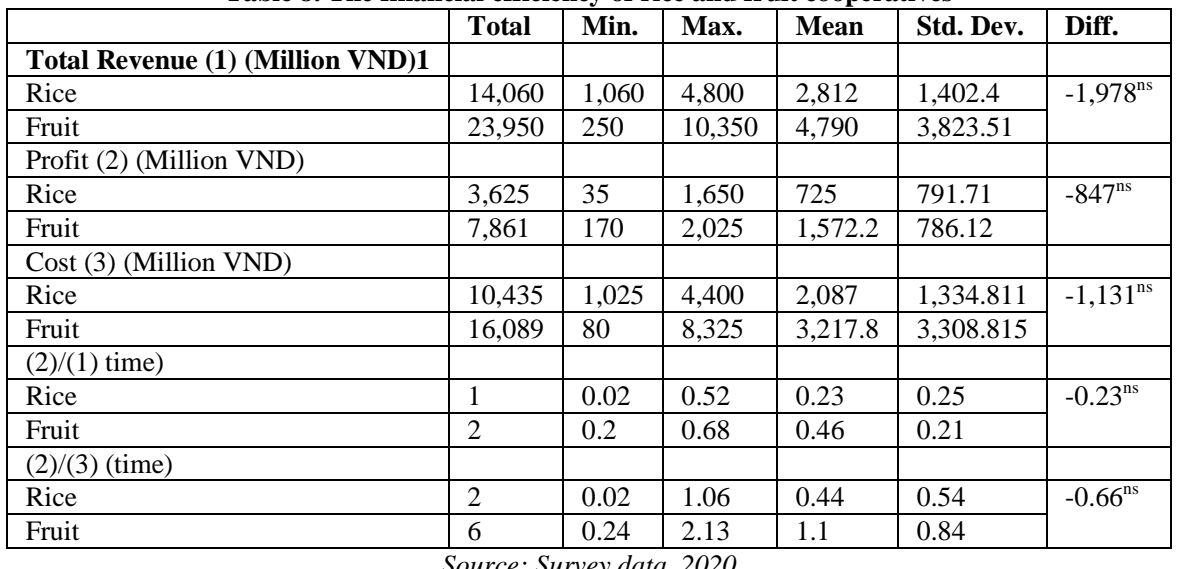

Note: $* * *$ and $*$ are statistically significant at $1 \%$ and $10 \%$ level, respectively and ns is not statistically significant; 1 US $\$ 1$ was equal to 22,890 Vietnamese Dong (VND) on June 30th, 2021

\section{Perception and awareness in improving the operational efficiency of cooperatives}

Table 9. Analysis of expected activities to improve cooperatives activities
\begin{tabular}{|l|l|l|l|l|l|l|}
\hline Variable & N & Mean & Std. Dev. & Min. & Max. & Perceive level \\
\hline TC1 & 50 & 4.4 & 0.52 & 4 & 5 & Completely agree \\
\hline TC2 & 50 & 4.8 & 0.42 & 4 & 5 & Completely agree \\
\hline TC 3 & 50 & 3.3 & 0.68 & 2 & 4 & Normal \\
\hline TC4 & 50 & 3 & 0.94 & 2 & 5 & Normal \\
\hline TC5 & 50 & 3.9 & 0.74 & 3 & 5 & Agree \\
\hline TC6 & 50 & 4.3 & 0.48 & 4 & 5 & Completely agree \\
\hline TC7 & 50 & 4.5 & 0.53 & 4 & 5 & Completely agree \\
\hline TC8 & 50 & 4.2 & 0.63 & 3 & 5 & Agree \\
\hline
\end{tabular}

Note: these criteria were determined through focus group discussions and expert interviews (KIP). In which, TCl: the formation of linkage chains between cooperatives and processing factories; TC2: the market price when the parties meet together and fix the price to buy at the time of harvest, TC3: the fixed price that the parties have determined at the beginning and do not change when harvesting. TC4: Shared price: Before the crop, the parties determine a standard price, if the standard price is different from the local market price, each party will bear 50\% of the difference, TC5: The enterprise determines with the cooperative on handling pest control costs, in which, the enterprise will handle all cases of pests and diseases during the crop with a fixed cost, TC6: Drying service, TC7: Storage service, warehouse rental, TC8: Agricultural transportation service products from copper to the place of consumption.

The research results clearly show that the cooperatives would like to (i) participate in value chain linkages, (ii) competitive prices are decided by the two parties, (iii) provide more post-harvest services, and (iv) have product storage. In which, fixed or halved prices are often unpopular because then the market power from producers and cooperatives will be reduced. In addition, technical support and delivery services are also interested, but at the normal level. When asked to rate the effectiveness of solutions mentioned above, respondents also agreed with the relevant standards and expectations listed above. This result is consistent when their wishes are expressed through personal judgments about the benefits of aspects to be achieved soon.

Table 10. Perception of expected efficiency of activities helping cooperatives operate effectively

\begin{tabular}{|l|l|l|l|l|l|l|}
\hline Variable & $\mathbf{N}$ & Mean & Std. Dev. & Min. & Max. & Perceive level \\
\hline TC1 & 50 & 4.2 & 0.423 & 4 & 5 & Agree \\
\hline TC2 & 50 & 3.9 & 0.316 & 3 & 4 & Agree \\
\hline TC3 & 50 & 2.7 & 0.675 & 2 & 4 & Normal \\
\hline TC4 & 50 & 3.2 & 0.019 & 2 & 4 & Normal \\
\hline TC5 & 50 & 4 & 0.816 & 3 & 5 & Agree \\
\hline TC6 & 50 & 3.8 & 0.632 & 3 & 5 & Normal \\
\hline TC7 & 50 & 3.9 & 0.316 & 3 & 4 & Normal \\
\hline TC8 & 50 & 3.8 & 0.422 & 3 & 4 & Normal \\
\hline \multicolumn{7}{|c|}{ Source: Survey data, 2020 } \\
\hline
\end{tabular}




\section{Perception about determinants of cooperatives operate effectively in the future}

The map below indicates the perception of cooperative managers think in order to operate effectively including expanding production scale, buildingspecific and effective production plans, promoting the development of more business services should be made a priority. Consumption assistant, clear assignment of specific tasks and responsibilities, strengthening linkages between financial institutions and enterprises, and clear policies all achieved an average value of 4.5 - 4.8 points as the highest level (the highest score is 5). Cooperatives managers indicated that expanding the production scale will bring higher profits and create jobs for members when the cooperative operates effectively. The criteria for developing a specific plan are clear, with an average value of $4.6 / 5$, showing that if the business plan is clearly in line with the set goals, in addition to saving costs in production, the cooperative can also identify main agricultural products for export. The business of adding services in the cooperative is also being implemented a lot in some cooperatives in Hau Giang province because these are the services that bring the second source of profit for the cooperative because the ability to contribute capital of cooperative members is still limited. Next is the activity of clearly assigning tasks and responsibilities with an average value of $4.5 / 5$, this activity helps the management board to develop the strengths of each individual. Strengthening linkages with credit institutions and businesses achieved an average value of $4.8 / 5$, this is the highest score assessed by cooperatives because this is an activity that brings capital to cooperatives when linking with credit institutions. Product use and consumption are promoted when linking with processing enterprises to create value-added products. Finally, the policy must be clear so that the cooperative will receive the right support from the local government. This result is similar to the announcement from GSO showing that cooperatives across the country currently have basic limitations in terms of personnel, administration, quality management of products and services, production, and business planning (GSO, 2020).

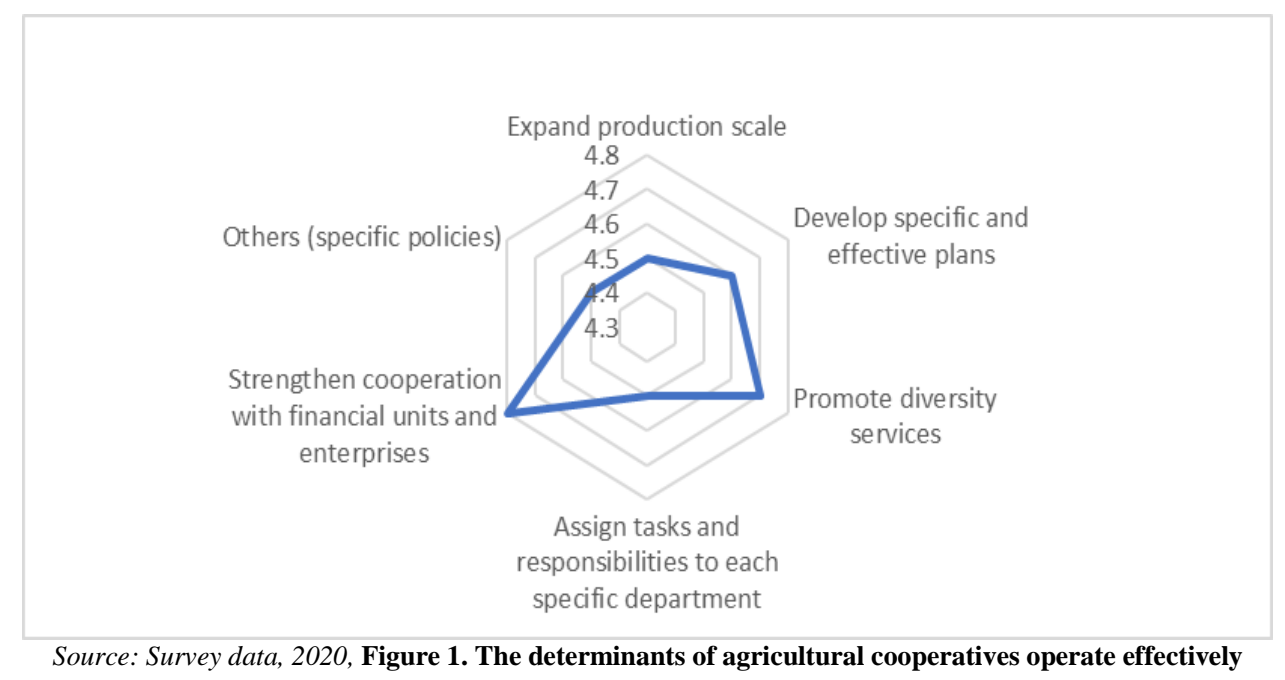

\section{Recommendations to develop agricultural cooperatives effectively}

\begin{tabular}{|c|c|c|}
\hline SWOT & $\begin{array}{l}\text { Chance }(\mathrm{O}) \\
\text { O1: Support of local authorities. } \\
\text { O2: Increasing demand for agricultural products } \\
\text { O3: Development of local tourism sector. } \\
\text { O4: Low production cost and labor cost. }\end{array}$ & $\begin{array}{l}\text { Threats }(\mathrm{T}) \\
\text { T1: Prices of inputs and agricultural } \\
\text { products are not stable. } \\
\text { T2: The export market is not stable. } \\
\text { T3: Quality of inputs are not guaranteed } \\
\text { T4: Weak competition power of } \\
\text { cooperatives. }\end{array}$ \\
\hline
\end{tabular}


Tien Dung Khong. Perception and efficiency analysis of agricultural cooperatives: a case study in Hau Giang province, Vietnam.

\begin{tabular}{|c|c|c|}
\hline \multicolumn{3}{|c|}{ Table 11. Continued... } \\
\hline $\begin{array}{l}\text { Strengths (S) } \\
\text { S1: Enthusiatics of manager board. } \\
\text { S2: Able to adapt to the market situation, } \\
\text { good communication skills. } \\
\text { S3: Rural transportation is developed }\end{array}$ & $\begin{array}{l}\mathrm{S} 1,2+\mathrm{O} 1,2,3,4: \text { Developing new products and } \\
\text { services (R\&D) } \\
\text { S2, S3+O2, O3: Domestic and international } \\
\text { market penetration and development. }\end{array}$ & $\begin{array}{l}\mathrm{S} 1,2,3+\mathrm{T} 1,4 \text { : Building a quality raw } \\
\text { material area. } \\
\text { S1,S2,S3+T2,T4: Market development } \\
\text { and stabilization. }\end{array}$ \\
\hline $\begin{array}{l}\text { Weakness (W) } \\
\text { W1: The management capacity and } \\
\text { professional qualifications of the } \\
\text { manager board are still limited } \\
\text { W2: Lacking working capital } \\
\text { W3: Outdated production equipment and } \\
\text { harvesting technology. } \\
\text { W4: Lack of market information }\end{array}$ & $\begin{array}{l}\text { W1+O1:Training and developing qualified } \\
\text { human resources. } \\
\text { W2,3+O1:Mobilizing capital for investment in } \\
\text { new technology equipment. } \\
\text { W4+O2: Develop local brand. }\end{array}$ & $\begin{array}{l}\text { W1,4+T4: Improve the level of the } \\
\text { management team. }\end{array}$ \\
\hline
\end{tabular}

\section{CONCLUSION}

Through the study of awareness and evaluation of the performance of agricultural cooperatives in Vietnam with Hau Giang province as a case study, this research identified the determinants of the efficiency and development of agricultural cooperatives, including resource and organizational factors, qualification of manager board. If these factors are improved in the future, cooperatives will have many opportunities to effectively connect with markets and government policies. The form of operation of cooperatives is mainly agricultural services, however, there are several agricultural cooperatives in rice and fruit trees that do not only operate in agricultural services but also include services such as mechanization, seed production, and consumption. Most of the rice and fruit crop cooperatives operate effectively. It shows that the operating model of agricultural cooperatives is mostly the same and there is no difference in organizational form. The rice and fruit crop cooperatives identified that the activities will bring high efficiency if implemented in the coming time, including activities to diversify products by strengthening linkages with processing enterprises, meet and fix prices when harvesting, and sign contracts for technical support and disease coverage with enterprises. Through SWOT analysis, it shows that the development strategy of agricultural cooperatives should focus on diversifying forms of activities and organizing market linkages, supporting product output, increase operating capital through capital mobilization, infrastructure investment, market consolidation and scientific and technical development, capacity building of cooperatives through training and continuous training. In order to overcome the current weaknesses of cooperatives, they should expand their production scale, develop specific and effective plans, promote the development of more output services, and assign tasks clearly with specific services to improve the performance. From the above analysis, this research proposes that policymakers need to implement the following solutions (i) To step by step strengthen and create a trust for cooperative members in the cooperatives, the board of directors must have specific business activities and plans that bring practical benefits. (ii) Increase the diversification of production and business activities of the cooperative by strengthening cooperation with processing enterprises to create value-added products to meet the needs of members and contribute to increasing profits of the cooperative. (iii) Strengthen the capacity and operational efficiency of cooperatives on the principles of voluntariness, autonomy, selfresponsibility, and equality in cooperative management; step by step modern governance, able to compete and adapt to market changes; innovate, increase the application of science and technology. (iv) Improving the capacity and qualifications of the cooperative management staff, especially the head of the cooperative, not only needs to have the knowledge and skills of an entrepreneur but also to have a devoted heart for the community. The newtype cooperative is a progressive economic institution that creates benefits, increases incomes, and takes the interests of its 
member. (v) Promote propaganda and awareness-raising on collective economic development, cooperatives, and member attraction, building, developing, and replicating models of cooperatives and unions of cooperatives, production, and business cooperation groups associated with the value chain of key products of the country, region, and locality. (vi) Develop a master plan on key products, goods, and services at national, regional, and local levels in association with enterprises investing in processing plants, logistics systems, and supermarkets. (vii) In addition, strengthening international cooperation activities, expanding relations, effectively exploiting resources, experience, science, and technology from international organizations in service of economic development. (viii) Improve the sense of responsibility of each member, constantly innovating production-business methods and management methods to suit market needs. (ix) Organize the process throughout for cooperatives and enterprises to sign contracts such as a supply of materials and seeds; providing assistant in product consumption for members; guiding the technical process and purchasing input for the cooperative members. (x) Strengthen the link between cooperative members to learn and cultivate more skills in farming production.

Acknowledgement: The data in this study provided in part by Project Code B2020TCT-05

\section{Conflict of Interest: None}

\section{Source of Funding: None}

\section{REFERENCES}

1. Bui Thong Nhat, 2010. Assessing influencing factors and proposing some solutions to improve the business performance of agricultural cooperatives in Can Tho city. Master thesis. Can Tho University.
2. Chu Hoang Hiep, 2015. Development of Cooperative Types in Ha Giang Province. Master thesis. University of Economics Hanoi National University.

3. Do Thi Hong Hanh, 2018). The actual situation of production and business activities of agricultural cooperatives in Bac Kan province. Journal of Science and Technology, No. 188, pp. 27-32.

4. Duong Ngoc Thanh et al., 2018. Evaluation of factors affecting the performance of agricultural cooperatives in An Giang province. Scientific Journal of Can Tho University, No. 4, pp. 212219.

5. GSO, 2020. General Statistics Year Book of Vietnam. General Statistic Office. Hanoi, Vietnam.

6. Monteiro, N. P., \& Straume, O. R. (2018). Are cooperatives more productive than investor-owned firms? Cross-industry evidence from Portugal. Annals of Public and Cooperative Economics, 89(2), 377414.

7. Nguyen Cong Binh, 2007. Measures to improve the performance of agricultural cooperatives in Tien Giang province to 2015. Master thesis. University of Economics Ho Chi Minh City.

8. Nguyen Thien Phuc, 2011. Situation and solutions to improve the efficiency of production and business activities of agricultural cooperatives in Hau Giang province. Master thesis. Can Tho University.

9. Nguyen Tien Dinh and Hoang Vu Giang, 2016. Analysis of the role of agricultural cooperatives in linking rice consumption in the Mekong Delta. Science magazine

10. Nguyen Van Tuan and Nguyen Van Sanh, 2015. Tien Dat Agricultural Cooperative, Vinh Loi district, benefits members. Scientific Journal of Can Tho University, No. 26, pp. 23-30.

11. Nguyen Van Tuan, 2013. Situation and proposed solutions to improve the operational efficiency of agricultural cooperatives in Bac Lieu province. Graduate thesis. Can Tho University. Summary report on Science and Technology at school level. Can Tho University. 
Tien Dung Khong. Perception and efficiency analysis of agricultural cooperatives: a case study in Hau Giang province, Vietnam.

12. Soboh, R., Oude Lansink, A., \& Van Dijk, G. (2012). The efficiency of cooperatives and investor-owned firms was revisited. Journal of Agricultural Economics, 63(1), 142-157.

13. Sexton, R. J., \& Iskow, J. (1993). What do we know about the economic efficiency of cooperatives: an evaluative survey. Journal of Agricultural Cooperation, 8(1141-2016-92584), 15-27.

14. Vietnam Cooperative Alliance, 2019 Annual Report 2019. Retrieved on July 30th 2021 from http://vca.org.vn/en/annual-report-2019a122.html.

How to cite this article: Khong TD. Perception and efficiency analysis of agricultural cooperatives: a case study in Hau Giang province, Vietnam. International Journal of Research and Review. 2021; 8(9): 154-164. DOI: https://doi.org/10.52403/ijrr. 20210922 